cholecystectomy, however, is generally done by one person, and it is difficult for anyone other than the operating surgeon to observe what is taking place. How do Baxter and O'Dwyer propose to teach the minilaparotomy procedure to surgeons in training, particularly if future trainees have little or no experience with the open operation?

Perhaps the most pressing reason for leaving minilaparotomy cholecystectomy out of the equation at this stage is that it is not yet recognised as a routine procedure.

H T KHAWAJA H A BRADPIECE W C CHAPMAN

Department of Surgery,

London SE5 9RS

Baxter JN, O'Dwyer PJ. Laparoscopic or minilaparotomy cholecystectomy? BMF 1992;304:559-60. (29 February.) Cameron JL, Gadacz TR. Laparoscopic cholecystectomy. An Surg 1991;213:1-2.

3 Peters JA, Ellison EC, Innes JT, Liss JL, Nichols KE, Loman $\mathrm{JM}$, et al. Safety and efficacy of laparoscopic cholecystectomy. A prospective analysis of 100 initial patients. Ann Surg 1991;213:3-12.

4 Southern Surgeons Club. A prospective analysis of 1518 laparoscopic cholecystectomies. N Engl f Med 1991; 324:1073-8.

\section{Low protein diets in chronic renal insufficiency}

SIR,-In their meta-analysis of studies of low protein diets in chronic renal insufficiency D Fouque and colleagues state that the analysis was restricted to randomised, controlled prospective studies that did not include diabetic patients. They then list 18 studies that were retrospective or non-controlled or had crossover design and two studies of diabetic patients. This list seems unnecessary. Table I lists 16 studies that seem to fit the authors' criteria for consideration, yet only six were selected and one of these is unpublished. It is not clear why the remaining 10 were excluded.

For one of the six studies selected ${ }^{2}$ the most recently published follow up of the study population was not used. ${ }^{3}$ The dietary prescription was heterogeneous in the studies selected, with the dietary protein intake in the treated group in one study being identical with the intake in a contro group in another study. In one study no significan dietary difference was observed between the control and treatment groups ${ }^{4}$; any effect on renal death in this study is unlikely to have been due to this non-significant intervention.

The authors conclude in the abstract that low protein diet delays the onset of end stage renal disease and then seem to contradict themselves in the discussion when they state that the diet does not reduce the progression of renal disease. It is difficult to see how a reduction in renal deaths in the treatment group fails to represent a reduction in the progression of renal disease as the fall in glomerular filtration rate is linear with time for many renal diseases.

I believe that this paper does little to help understanding of the place of a low protein diet in the management of chronic renal failure.

\section{Department of Laboratory Medicine} and Pathology,

University of Minnesota Medical School,

Box 198 UMHC

Minneapolis,

MN 55455-0385, USA

1 Fouque D, Laville M, Boissel JP, Chiffet R, Labeeuw M, Zech $P Y$. Controlled low protein diets in chronic renal insufficiency meta-analysis. $B M \mathcal{F}$ 1992;304:216-9. (25 January.)

2 Rosman JB, Ter Wee PM, Meijer S, Piers-Becht TPM, Sluite WJ, Donker AJM. Prospective randomised trial of early dietary protein restriction in chronic renal failure. Lance 1984;ii:1291-5.

3 Rosman JB, Langer K, Brandl M, Piers-Becht TPM, Van De Hem GK, Ter Wee PM, et al. Protein-restricted diets in chronic renal failure: a four year follow-up shows limited indications. Kidney Int Suppl 1989;36:S96-102.
4 Locatelli F, Alberti D, Graziani G, Buccianti G, Redaelli B Giangrande A, et al. Prospective, randomised, multicentre trial of effect of protein restriction on progression of chronic ren insufficiency. Lancet 1991;337:1299-304.

5 Williams PS, Fass G, Bone JM. Renal pathology and proteinuria determine progression in untreated mild/moderate chronic renal failure. $Q$ f Med 1988;252:343-54.

AUTHORS' REPLY,-Several of James D Walker's points deserve further comment because they were probably underdeveloped in our report. ${ }^{1}$ We found 28 trials in the literature, of which we rejected 22 because they were not randomised, leaving six for the meta-analysis. Reports of meta-analysis should give the rejected trials and the reasons for exclusion. Hence we listed the 22 studies that did not fit our selection criteria.

The most recent results from the study of Rosman $e t a l^{2}$ do not differ, as far as the end point of interest to us was concerned, from those in their previous paper. ${ }^{3}$ They reported a trend towards fewer renal deaths in patients treated with protein restricted diets, although this was not significant.

As Walker says, the dietary prescription was heterogeneous, but the gradient of protein intake between treated and control subjects was considered to be the therapeutic factor: there is no consensus on the ideal protein restriction during chronic renal failure.

The $40 \%$ reduction in renal deaths observed in the Italian study, even if not significant ${ }^{4}$ was observed for a true restriction of $0.2 \mathrm{~g} / \mathrm{kg} /$ day instead of the $0.4 \mathrm{~g} / \mathrm{kg} /$ day prescribed, as recalculated by Gretz and Strauch. ${ }^{5}$ Although statistica tests did not show a difference in protein intakes between the two groups, that does not prove that there was no difference (type II error). Patients protein intakes were reduced and fewer rena deaths occurred in the low protein group. We believe that this reduction would have been greate if better compliance had been achieved.

If end stage renal disease is delayed by low protein diets this may result from a reduction in the progression of chronic renal failure or a reduction in uraemic symptoms, and from our end point it is not possible to decide. But, as Levey and Shah showed, special attention must be given to the precision of glomerular markers in measuring renal function and progression of severe rena failure ${ }^{67}$ From the patient's and the health economist's point of view, however, what is important is whether or not the patient is receiving dialysis, and thus dialysis is the marker of clinical renal death.

D FOUQUE M LAVILLE M LABEEUW

Service de Néphrologie,

P ZECH

Hôpital Edouard Herriot

69437 Lyon Cedex 03,

France

J P BOISSEL

Laboratoire de Pharmacologie Clinique, R CHIFFLE

69424 Lyon

France

1 Fouque D, Laville $M$, Boissel JP, Chifflet R, Labeeuw $M$ Zech $\mathrm{P}$. Controlled low protein diets in chronic renal failure: meta-analysis. $B M \mathcal{F}$ 1992;304:216-20. (25 January.)

2 Rosman JB, Langer K, Brandl M, Piers-Becht TPM Van Der Hem GK, Ter Wee PM, et al. Protein-restricted dits in Hem GK, Ter Wee PM, et al. Protein-restricted diets chronic renal failure: a four year follow-up

Rosman JB, Ter Wee PM, Meijer S, Piers-Becht TP, Sluiter WJ, Donker AJ. Prospective randomised trial of early dietary Donker AJ. Prospective randomised trial of early dietary protein $1291-5$.

4 Locatelli F, Alberti D, Graziani G, Buccianti G, Redaelli B, Giangrande A, et al. Prospective, randomised, multicentre tri of effect of protein restriction on progression of chron renal insufficiency. Lancet 1991;337:1299-304.

5 Gretz N, Strauch M. Low-protein diet and chronic renal failure. Lancet 1991;338:442.

Levey A. Nephrology forum: measuring renal function. Kidney Int 1990;38:167-84.

7 Shah BV, Levey A. Spontaneous changes in the rate of decline in reciprocal serum creatinine: errors in predicting the progression of renal disease from extrapolation of the slope. Joumal of the American Society of Nephrology 1992;2:1186-91.

\section{Assessing resuscitation skills by} video recording

SIR,-Assessment of candidates attending advanced trauma life support courses includes the use of multiple choice questionnaires and "moulage." How closely theoretical knowledge and practical performance during mock events relate to the management of true resuscitation is unclear.

We have been using a video camera to monitor the management of patients with trauma and with cardiac arrest in the accident and emergency department and believe that this method is useful both in training and in audit. Video recording of care in cases of trauma has been used in the United States for several years, ${ }^{2}$ and we have reported our experience in patients with trauma: by reviewing many such cases we identified deficiencies in the organisation and design of the resuscitation room and made improvements.

We have extended the method to monitor the management of cardiac arrest in the department. This has allowed us to pinpoint both organisational and individual deficiencies. For example, in the first 10 cases the mean number of staff concerned in each attempted resuscitation was 10.6 (range 7 13) and the mean longest interruption in cardiac massage during resuscitation was 23.3 seconds. The video recording, which is erased after one week, may be viewed in the presence of a senior member of the department by the members of staff who participated in the resuscitation.

Despite initial reservations on the part of some of the medical and nursing staff the method is now well accepted, and we find it useful in assessing resuscitation in practice.

CLIVE WESTON

Departments of Epidemiology and Cardiology, University Hospital of Wales Cardiff CF4 4XW

PETER RICHMOND MICHAEL MCCABE RUPERT EVANS ROGER EVANS

Accident and Emergency Department,

Cardiff Royal Infirmary

Cardiff CF2 1SZ

I Nolan JP, Forrest FC, Baskett PJF. Advanced trauma life support courses. BMF 1992;304:654. (14 March.)

2 Hoyt DB, Shackford SR, Fridland PH, Mackersie RC, Hansborough JF, Wachtel TL, et al. Video-recording trauma resuscitations: an effective teaching technique. $\mathcal{f}$ Trauma 1988;28:435-40.

3 Murray L, McCabe $M$. The video-recorder in the accident and emergency department. Arch Emerg Med 1991;8:182-4.

\section{Screening for cervical cancer in developing countries}

SIR, - Veena Singh and colleagues' assessment of the efficacy of visual screening for cervical cancer ${ }^{1}$ is valid only for women attending maternal and child health clinics run by doctors trained in gynaecology. If direct visual inspection is to be useful in developing countries, where cytological screening is not available, the countries need to overcome many problems before achieving the basic level of screening for women generally. The problems are threefold.

Firstly, women in some developing countries are not valued. In an editorial Amartya Sen explains the reasons for this and suggests that women's illiteracy is one of the causes of their relative neglect. ${ }^{2}$ Women in developing countries need education to empower them to lead healthy productive lives. This may be a long way off during the current world recession. Without education they may not be able to decide to seek screening services, which would no doubt be concentrated in cities. Their day to day survival is more important than screening for health. In a study of whether 